\title{
PENGARUH MOTIVASI DAN PERILAKU APARATUR BIROKRASI TERHADAP KUALITAS PELAYANAN KESEHATAN DI KOTA PALU: Studi Pada Puskesmas di Kota Palu Provinsi Sulawesi Tengah
}

\author{
Mustainah \\ Program Pasca Sarjana Universitas Padjadjaran \\ Email:mustainah@unpad.ac.id
}

\begin{abstract}
ABSTRAK. Masalah pokok dalam penelitian ini adalah kualitas pelayanan kesehatan di Kota Palu yang dilakukan pada Puskesmas selaku pengelola teknis yang belum optimal, dan motivasi dan perilaku aparatur birokrasi dalam memberikan perlayanan masih rendah. Penelitan ini bertujuan untuk mengkaji, menganalisis, dan mendapatkan konsep baru tentang teori motivasi dan perilaku aparatur birokrasi terhadap kualitas pelayanan kesehatan. Metode yang digunakan adalah explanatory survey method dengan pendekatan kuantitatif. Teknik penarikan sampel yaitu stratified random sampling. Teknik pengumpulan data menggunakan angket, dengan jumlah responden 125 orang paramedis. Teknik analisis data adalah analisis jalur dengan uji statistika adalah uji-t dan uji-F. Hasil penelitian ini menunjukkan bahwa terdapat pengaruh yang signifikan antara motivasi aparatur dan perilaku aparatur birokrasi terhadap kualitas pelayanan kesehatan. Motivasi aparatur pengaruhnya besar terhadap kualitas pelayanan kesehatan di puskesmas Kota Palu. Dimensi motivasi yang paling dominan terhadap kualitas pelayanan kesehatan adalah dimensi pengembangan. Sedangkan perilaku aparatur pengaruhnya terhadap kualitas pelayanan kesehatan di puskesmas Kota Palu dikategorikan cukup. Dimensi perilaku yang paling dominan pengaruhnya terhadap kualitas pelayanan kesehatan adalah dimensi tanggung jawab.
\end{abstract}

Kata Kunci: Motivasi, Perilaku, Pelayanan di Puskesmas

\section{THE INFLUENCE OF MOTIVATION AND THE BEHAVIOR OF BUREAUCRACY APPARATUS TOWARD SERVICE HEALTH IN THE MUNICIPALITY OF PALU: A Study to Puskesmas in the municipality of Palu middle Sulawesi Province}

ABSTRACT. The main problem in this study is the quality of health services in Palu. It is conducted in health services centers as the technical implementer. It seems not optimal yet, and the motivation and behavior of the bureaucratic apparatus in providing services is still low. This research aims to asses, analyze, and get a new concept of motivation theory and the behavior of bureaucratic apparatus to quality health services. Explanatory method used is survey method with quantitative approach. Technical sampling used is stratified random sampling. Data collected by using questionnaires, with the number of respondents are 125 paramedics. Data analysis technique is path analysis with a statistical test is $t$-test 
and test- $F$. The result of this study indicates that there is significant influence between motivation and behavior of the apparatus bureaucratic apparatus to quality health services. Motivation apparatus large influence on the quality of service health at Health service centre of Palu. The most dominant motivation dimension to quality health care is dimension of development. While the behavior of the apparatus influence on the quality of health services in health centers is categorized enough. Behavior dimensional of the most dominant influence on the quality of health care is dimension of responsibility.

Keyword: Motivation, Behavior, Service, at Health service centre.

\section{PENDAHULUAN}

Semua warga negara mangakui bahwa kesehatan menjadi modal terbesar untuk mencapai kesejahteraan. Oleh karena itu kesehatan pada dasarnya merupakan suatu investasi sumber daya manusia untuk mencapai masyarakat yang sejahtera (welfare society).

Derajat kesehatan memiliki posisi dan peranan yang penting dalam mengukur kemajuan suatu bangsa, oleh karena itu derajat kesehatan dijadikan salah satu indikator pada Human Development Index (HDI) atau Index Pembangunan Manusia (IPM). Untuk mewujudkan derajat kesehatan yang baik, maka pemerintah memberikan pelayanan kesehatan kepada seluruh warganya. Secara formalnya untuk memberikan pelayanan kesehatan telah dicantumkan dalam Undang-Undang Nomor 23 Tahun 1992 tentang kesehatan pasal 4 yang menyebutkan bahwa setiap orang mempunyai hak yang sama dalam memperoleh derajat kesehatan yang optimal.

Dalam penjelasan dokumen Rencana Strategi Kementerian Kesehatan Tahun 2010-2014, menjelasdkan bahwa pelayanan kesehatan yang dihadapi oleh pemerintah terkait dengan keterbatasan sarana pelayanan kesehatan, jumlah dan jenis tenaga kesehatan yang belum memenuhi kebutuhan, belum .meratanya distribusi tenaga kesehatan, masih rendahnya kualitas tenaga kesehatan, belum berjalannya pengembangan karier, sistem penghargaan, dan sanksi sebagaimana mestinya.

Sejalan dengan undang-undang tersebut pemerintah Kota Palu melakukan berbagai usaha untuk meningkatkan derajat kesehatan masyarakat di daerahnya. Hal ini tercermin pada pelaksanaan pembangunan Kota Palu. Salah satu pelaksanaan pembangunan adalah pembangunan di bidang kesehatan dan peningkatan pelayanan kesehatan bagi masyarakat melalui pelayanan kesehatan dasar di puskesmas dan pemberian pelayanan rujukan ke Rumah Sakit Umum Daerah.

Berdasarkan profil Kesehatan Kota Palu, 2008: menunjukkan fenomena pelayanan kesehatan kepada masyarakat di Kota Palu, jumlah penduduk yang memperoleh jaminan kesehatan pada Tahun 2008 berjumlah 44, 49\%, Tahun 2009 berjumlah 49, 88\%. Sedangkan jumlah penduduk yang belum mendapatkan 
jaminan kesehatan pada Tahun 2008 berjumlah 50, 51\% dan pada Tahun 2009 sebesar 50, 12\%. Dari Profil tersebut diketahui bahwa Angka Kematian Ibu (AKI) di Kota Palu masih menunjukkan cukup tinggi. Angka Kematian Ibu pada Tahun 2007 berjumlah 9 orang atau 153 per 100.000 kelahiran hidup, Tahun 2008 AKI berjumlah 7 orang atau 103 per 100.000 kelahiran hidup.

Kunjungan masyarakat ke Puskesmas yang mengalami penurunan selama tiga tahun (Tahun 2006- 2007) berdasarkan Profil Kesehatan Tahun 2009. Jumlah kunjungan masyarakat ke Puskesmas Kota Palu pada Tahun 2006-2007 sebanyak 7,63 persen, pada Tahun 2007-2008 berjumlah 0,27 persen, dan pada Tahun 2008-2009 berjumlah 5,01 persen. Uraian ini menunjukkan bahwa puskesmas belum dijadikan sebagai pelayananan kesehatan dasar atau pelayanan tingkat pertama (menjaring jenis penyakit) bagi masyarakat Kota Palu.

Konteks penelitian ini, menunjukkan bahwa tingkat pelayanan kesehatan masyarakat di Puskesmas Kota Palu belum sesuai dengan harapan masih rendah disebabkan karena tenaga kesehatan di unit pelayanan masih kurang, mobilitas tenaga kesehatan cenderung menuju daerah perkotaan, distribusi tenaga kesehatan masih rendah, situasi geografis, demografis dan sosial budaya masyarakat Kota Palu yang kurang mendukung pelaksanaan program kesehatan.(Profil Kesehatan Kota Palu, 2009). Peranan puskesmas yang sejak semula dirancang untuk menjadi pusat pelayanan kesehatan masyarakat, pusat pembinaan kesehatan masyarakat dan pusat pengembangan kesehatan belum banyak mengalami perubahan. $\mathrm{Di}$ tengah-tengah semakin berkembangnya berbagai jenis pelayanan kesehatan. Selain itu puskesmas merupakan pelayanan kesehatan dasar. Yang dimaksud dengan pelayanan kesehatan dasar adalah pelayanan kesehatan yang bersifat pokok, yang sangat dibutuhkan oleh sebagian besar masyarakat serta mempunyai nilai strategis untuk meningkatkan derajat kesehatan masyarakat. Pada umumnya pelayanan kesehatan tingkat pertama bersifat pelayanan rawat jalan tingkat pertama.

Puskesmas dalam menjalankan tugas pelayanan kesehatan masyarakat masih belum mencapai tujuan yang diinginkan, secara umum masih terdapat banyak kelemahan yang dapat diamati antara lain :

1. Motivasi dan profesionalisme aparatur birokrasi dalam memanaj puskesmas masih lemah.

2. Puskesmas belum serius pada kepuasan masyarakat pengguna layanan kesehatan pasien. Dengan anggapan bahwa masyarakatlah yang membutuhkan puskesmas bukan yang sebaliknya masih melekat pada staf puskesmas.

3. Pengembangan sumber daya manusia belum mendapat perhatian yang serius.

Untuk memunuhi kebutuhan dan tantangan pembangunan kesehatan, sejalan dengan otonomi daerah pemerintah daerah wajib mengembangkan kebijakan untuk meningkatkan kualitas pelayanan kesehatan. Tenaga kesehatan di daerah 
baik tenaga medis maupun paramedik menjawab kebutuhan masyarakat di bidang kesehatan.

Berdasarkan uraian pelayanan kesehatan di Kota Palu serta faktor- faktor yang mempengaruhinya, dapat dikemukakan bahwa belum optimalnya pelayanan kesehatan kepada masyarakat. Hal ini terkait dengan motivasi dan perilaku aparatur yang bertugas di Puskesmas Kota Palu.

Berdasarkan uraian di atas bahwa kualitas pelayanan kesehatan bukan hanya berkaitan pada fasilitas gedung, ketersediaan dana ataupun peralatan yang telah tersedia. Faktor lain yang perlu diperhatikan adalah hubungan antara aparatur (tenaga kesehatan) sebagai pemberi pelayanan dengan masyarakat yang dilayani. Hal ini ada hubungannya dengan motivasi dan perilaku aparatur. Berpatokan pada uraian pelayanan kesehatan di puskesmas Kota Palu dan faktor yang mempengaruhinya, maka dipandang perlu untuk diteliti lebih mendalam dilihat dari aspek motivasi dan perilaku aparatur.

Dengan mendasarkan kepada latar belakang di atas, maka peneliti merumuskan masalah; 1) Seberapa besar pengaruh motivasi aparatur birokrasi terhadap kualitas pelayanan kesehatan di Puskesmas Kota Palu; 2) Seberapa besar pengaruh perilaku aparatur birokrasi terhadap kualitas pelayanan kesehatan di Puskesmas Kota Palu. Dengan menjawab masalah tersebut, diharapkan dperoleh konsep baru dalam ilmu administrasi publik khususnya mengenai motivasi dan perilaku aparatur birokrasi terhadap kualitas pelayanan kesehatan.

\section{METODE}

Objek yang disoroti dalam penelitian ini adalah motivasi dan perilaku aparatur birokrasi terhadap kualitas pelayanan kesehatan di Kota Palu Propinsi Sulawesi Tengah. Disamping itu obyek yang diteliti adalah aparatur birokrasi yang terdiri dari perawat dan bidan yang dianggap memahami masalah kualitas pelayanan kesehatan sehingga hasil penelitian yang diperoleh dari aparatur birokrasi dapat diungkap secara obyektif dan komprehensif.

\section{Desain Penelitian}

Berdasarkan kerangka pemikiran yang telah dikemukakan maka beberapa variable penelitian perlu didefenisikan secara operasional adalah, Motivasi Aparatur Birokrasi $\left(\xi_{1}\right)$, Perilaku Aparatur Birokrasi $\left(\xi_{2}\right)$, sebagai variabel bebas. Sedangkan variabel terikat adalah Kualitas Pelayanan Kesehatan $(\eta)$. Untuk memudahkan pemahaman tentang makna variabel yang digunakan dalam penelitian ini, maka setiap variabel penelitian di defenisikan sebagai berikut:

1. Motivasi aparatur birokrasi $\left(\xi_{1}\right)$ adalah daya pendorong dalam diri aparatur untuk mengerahkan kemampuan, keahlian dan keterampilan dalam menyelesaikan tugas, yang dapat berwujud eksistensi(exixtence-E)), hubungan (relatedness- $R$ ), dan pertumbuhan (growth-G).

2. Perilaku Aparatur Birokrasi $\left(\xi_{2}\right)$ adalah cerminan tingkah laku aparatur birokrasi yang terdiri dari kedisiplinan, kepedulian, kepekaan dan tanggung jawab dalam 
melaksanakan kegiatan serta berinteraksi dengan masyarakat untuk memberikan pelayanan kepada masyarakat.

3. Kualitas pelayanan kesehatan $(\eta)$ adalah deskripsi pelayanan kesehatan yang diberikan oleh aparatur birokrasi berupa jasa yang memenuhi harapan masyarakat secara tepat dan efisien, yang mencakup: kecepatan, ketepatan, kemudahan, dan keadilan .

Masing-masing variabel penelitian, dan dimensi-dimensinya serta indikator akan diuraikan sebagai berikut:

1. Variabel $\xi_{1}$, motivasi aparatur birokrasi pada Puskermas Kota Palu yang disebut variabel bebas dengan dimensi sebagai berikut:

a. Eksistensi ini merupakan faktor yang pertama dalam motivasi yang mengatakan bahwa aparatur mempunyai kebutuhan-kebutuhan yang dipuaskan, dengan menggunakan indikator kondisi kerja, dan pendapatan.

b. Hubungan, adanya hubungan sosial merupakan suatu kebutuhan yang dipuaskan, dengan menggunakan indikator hubungan dengan masyarakat, dan hubungan antar pegawai dalam pekerjaan

c. Pertumbuhan, merupakan kebutuhan untuk peningkatan wawasan, pengetahuan, keterampilan, dan profesionalitas aparatur sehingga memenuhi kebutuhan diri sendiri, dengan menggunakan indikator pendidikan, pelatihan, prestasi kerja dan promosi.

2. Variabel $\xi_{2}$, yaitu perilaku aparatur birokrasi pada Puskesmas Kota Palu yang disebut variabel bebas dengan dimensi sebagai berikut:

a. Kepedulian, adalah sikap aparatur dalam memberikan pelayanan apakah memperlambat atau mengulur-ulur waktu dengan indikator bersikap ramah, mengenal pasien, pasien tidak menunggu lama.

b. Kedisiplinan, dengan adanya disiplin dalam pelayanan, mutu pelayanan semakin lebih baik. Menggunakan indikator kehadiran tepat waktu, kepatuhan dalam melaksanakan tugas, dan taat pada peraturan yang berlaku

c. Kepekaan yaitu kepekaan aparatur memahami masalah yang dihadapi masyarakat (pasien). Aparatur banyak mendengar keluhan dan mengatasinya diharapkan dapat meningkatkan kualitas pelayanan kesehatan, dengan indikator: pemahaman terhadap kebutuhan pasien, kemampuan untuk mengantisipasi masalah, keuletan dalam melaksanakan tugas.

d. Tanggung jawab adalah keadaan yang wajib menanggung segala sesuatu apabila terjadi apa-apa, dengan indikator: menyelesaikan pekerjaan sampai tuntas, ketelitian dalam memberikan pelayanan, pemahaman visi dan misi organisasi.

3. Variabel $\eta$ yaitu kualitas pelayanan kesehatan yang disebut variabel terikat (dependen) dengan dimensi-dimensi sebagai berikut:

a. Kemudahan yaitu proses melakukan aktivitas dengan tidak melelahkan, 
dengan indikator: petugas mudah dihubungi, puskesmas mudah dijangkau, mudah memperoleh informasi.

b. Kecepatan, yaitu waktu yang digunakan dalam memberikan pelayanan kepada pasien, dengan indikator: kecepatan merespon keluhan masyarakat, menyampaikan persyaratan administrasi, pemberian layanan secara cepat.

c. Ketepatan yaitu adanya ketepatan untuk menyediakan pelayanan pada saat aparatur bertugas, dengan indikator: ketepatan waktu, proses perlayanan, ketepatan biaya.

d. Keadilan yaitu tingkat perlakuan yang diberikan aparatur kepada masyarakat (pasien) adalah sama atau tidak diskriminatif, dengan indikator: bersikap netral, bersikap adil, berlaku jujur.

Dalam penelitian ini ukuran sampel ditentukan dalam bentuk uji statistika yang akan digunakan yaitu model persamaan struktural atau Struktural Equation Modeling (SEM). Menurut Hair et.al. (2006:605), jumlah sampel yang direkomendasikan untuk analisis Sruktural Equation Modelling berkisar antara 200 sampai dengan 400 responden. Sedangkan untuk menentukan jumlah sampel dengan menggunakan alat analisis SEM, Hair (2006) menyatakan bahwa ukuran sampel minimum adalah sebanyak 5 observasi untuk setiap estimasi parameter.

Dengan demikian estimasi paramater dalam penelitian ini adalah sebesar 25 , maka jumlah sampel minimum adalah $25 \times 5$ sebesar 125, maka besarnya sampel diambil sebanyak 125 aparatur.

\section{Rancangan Analisis}

Analisis yang digunakan terdiri atas dua jenis, yaitu: (1) analisis deskriptif terutama untuk variabel yang bersifat kualitatif, dan (2) analisis kuantitatif berupa pengujian hipotesis dengan menggunakan uji statistik. Bagian Pertama, analisis data dengan pendekatan "kualitatif", yang didasarkan data yang digali dari lapangan. Bagian Kedua, analisis data dengan pendekatan kuantitatif, yaitu dengan statistik Structural Equation Modeling' (SEM) yang didasarkan kepada jenis data yang dikumpulkan serta relevansinya terhadap tujuan penelitian.

Analisis data deskriptif dilakukan dengan membuat tabel distribusi frekuensi disertai dengan skor setiap item penelitian dengan tujuan dapat memberikan gambaran secara umum pendapat responden terhadap variabel yang sedang diteliti. Untuk memberikan gambaran secara lebih spesifik mengenai tingkat motivasi, perilaku, dan pelayanan kesehatan di puskesmas, digunakan panduan tabel kategori skor jawaban responden sebagai berikut: 
Tabel 3.4 Kategori Skor Jawaban Responden

\begin{tabular}{ccc}
\hline No & Interval Skore Penilaian (\%) & $\begin{array}{c}\text { Keterangan } \\
\text { Penilaian }\end{array}$ \\
\hline $\mathbf{1}$ & $84-100$ & Sangat Baik \\
\hline $\mathbf{2}$ & $68-83,99$ & Baik \\
\hline $\mathbf{3}$ & $52-67,99$ & Cukup Baik \\
\hline $\mathbf{4}$ & $36-51,99$ & Tidak Baik \\
\hline $\mathbf{5}$ & $20-35,99$ & Sangat Tidak Baik \\
\hline
\end{tabular}

\section{HASIL DAN PEMBAHASAN}

\section{Pengaruh Motivasi Terhadap Kualitas Pelayanan Kesehatan}

Permasalahan yang akan dijawab adalah seberapa besar pengaruh motivasi aparatur birokrasi terhadap kualitas pelayanan kesehatan di Puskesmas Kota Palu. Besarnya pengaruh motivasi aparatur birokrasi yang terdiri atas eksistensi (existance-E), hubungan (relatedness-R), pengembangan (growth $-\mathrm{G}$ ) terhadap kualitas pelayanan kesehatan diperlihatkan dengan nilai koefisien koefisien jalurnya. Diperoleh pengaruh motivasi aparatur birokrasi terhadap kualitas pelayanan kesehatan di puskesmas Kota Palu sebesar 0,55 standar deivasi. Sehingga dapat dikatakan bahwa besarnya pengaruh motivasi aparatur terhadap kualitas pelayanan kesehatan adalah 0.55 standar deviasi.

Dengan demikian hasil penelitian ini mengindikasikan bahwa semakin tinggi motivasi yang dimiliki aparatur di puskesmas Kota Palu yang dicerminkan oleh dimensi eksistensi, hubungan, dan pengembangan. Hal ini akan diikuti oleh semakin tinggi kualitas pelayanan kesehatan yang dilakukan oleh aparatur di puskesmas Kota Palu.

Secara teoritis dijelaskan bahwa baik buruknya kualitas pelayanan tergantung pada faktor-faktor yang mempengaruhinya. Hal tersebut sejalan dengan pendapat Thoha (2002:181), yang menyatakan bahwa "kualitas pelayanan kepada masyarakat sangat tergantung kepada motivasi aktor dan system yang dipakai". Sehingga untuk meningkatkan kualitas pelayanan kesehatan, perlu meningkatkan motivasi aparatur dalam melakukan kegiatan.

Hasil penelitian ini sejalan dengan hasil penelitian yang dilakukan oleh Sunarto (2008) yang menjelaskan bahwa motivasi kerja aparatur berpengaruh terhadap kualitas pelayanan. Motivasi aparatur akan lebih meningkat apabila disertai dengan perinsip penerapan kepentingan terintegrasi yaitu kepentingan organisasi seimbang dengan kepentingan pimpinan dan para pegawai. Motivasi mempengaruhi kinerja pegawai dalam pelayanan kesehatan. Motivasi tidak terlepas dari apa dan mengapa semangat kerja dibutuhkan. Aparatur tidak hanya diharapkan cerdas, mampu dan cakap dalam pekerjaan, tetapi juga harus memiliki semangat kerja yang tinggi untuk melaksanakan kepentingan publik. 
Dengan demikian, untuk meningkatkan kualitas pelayanan kesehatan, khususnya motivasi aparatur birokrasi merupakan hal yang perlu dilakukan yaitu untuk dapat menumbuhkan responsiveness aparatur (perawat dan bidan). Hasil penelitian ini mengindikasikan bahwa perubahan-perubahan pada motivasi aparatur birokrasi dapat mempengaruhi kualitas pelayanan kesehatan pada Puskesmas Kota Palu.

Berdasarkan hasil penelitian yang menunjukkan bahwa ada pengaruh motivasi aparatur terhadap kualitas pelayanan, maka hasil penelitian ini memberikan gambaran sebagai berikut:

Pertama, motivasi aparatur berpengaruh terhadap kualitas pelayanan kesehatan di puskesmas Kota Palu. Hal ini menunjukkan bahwa motivasi aparatur terdiri dari beberapa dimensi yaitu eksistensi, hubungan, dan pengembangan berpengaruh terhadap kualitas pelayanan kesehatan dengan dimensi mudah, cepat, tepat, dan adil.

Kedua, hasil penelitian ini, mendukung teori-teori yang menyatakan bahwa motivasi behubungan dengan kualitas pelayanan yang dikemukakan oleh R. Kanfer (dalam Jones dkk, 2000:427), Greene dkk (1985:109), dan Koehler and Rainey (2008:39).

\section{Pengaruh Perilaku Aparatur Birokrasi Terhadap Kualitas Pelayanan}

Permasalahan yang akan dijawab adalah seberapa besar pengaruh perilaku aparatur birokrasi terhadap kualitas pelayanan kesehatan di Puskesmas Kota Palu. Besarnya pengaruh perilaku aparatur birokrasi yang terdiri atas kepedulian, kedisiplinan, kepekaan dan tanggung jawab terhadap kualitas pelayanan kesehatan diperlihatkan dari koefisien jalurnya. Diperoleh pengaruh perilaku aparatur birokrasi terhadap kualitas pelayanan kesehatan di puskesmas Kota Palu sebesar 0,49 standar deviasi. Sehingga dapat dikatakan bahwa besarnya pengaruh motivasi aparatur terhadap kualitas pelayanan kesehatan adalah 0.49 standar deviasi atau dengan kata lain $24 \%$ keragaman dari kualitas pelayanan dipengaruhi oleh variabel keragaman prilaku aparatur birokrasi.

Hasil penelitian ini mengindikasikan bahwa semakin tinggi perilaku yang dimiliki aparatur di puskesmas Kota Palu yang dicerminkan oleh dimensi kepedulian, kedisiplinan, kepekaan, dan tanggung jawab. Hal ini akan diikuti oleh semakin tinggi kualitas pelayanan kesehatan yang dilakukan oleh aparatur di pusklesmas Kota Palu.

Berdasakan hasil analisis data diketahui bahwa dimensi-dimensi perilaku birokrasi memiliki kaitan erat dengan prilaku birokrasi sehingga perlu menjadi perhatian dalam upaya peningkatan kualitas pelayanan kesehatan. Hal ini sesuai dengan pendapat Siagian (1994:91) bahwa "perilaku yang diberikan oleh birokrasi kepada masyarakat adalah perilaku yang bersifat peduli, disiplin, peka dan tanggung jawab". Dari keseluruhan perilaku birokrasi ini tercermin pada pelayanan kepada masyarakat. 
Berdasarkan hasil penelitian tentang pengaruh perilaku aparatur birokrasi terhadap kualitas pelayanan kesehatan di puskesmas Kota Palu menunjukkan hasil sebesar 0.49 standar deviasi atau sebesar $24 \%$ keragaman dari kualitas pelayanan kesehatan dipengaruhi oleh keragaman perilaku aparatur, karena sebagian besar jasa publik masih ditentukan oleh aparatur birokrasi. Pada pembahasan ini, secara parsial dimensi perilaku aparatur birokrasi berpengaruh terhadap kualitas pelayanan kesehatan akan diuraikan sebagai berikut:

Untuk menciptakan aparatur birokrasi yang kondusif dan menimbulkan citra yang baik dimasa depan segenap aparatur birokrasi sebagai pelayan publik sebaiknya merubah perilakunya menjadi peduli terhadap aspirasi dan kebutuhan masyarakat sehingga masyarakat merasa terbantu.

Dimensi kedisiplinan terdiri dari kehadiran tepat waktu, kepatuhan dalam melaksanakan tugas, taat pada peraturan yang berlaku. Dimensi ini memiliki koefisien jalur sebesar 0.71 atau sebesar $50 \%$ perubahan dimensi ini dipengaruhi variabel prilaku aparatur birokrasi. Hasil analisis deskriptif memberikan nilai ratarata sebesar $71.3 \%$ masuk dalam kategori tinggi. Hasil ini memberikan gambaran bahwa kedisiplinan merupakan aspek yang penting diperhatikan terkait dengan prilaku aparatur birokrasi. Dengan rata-rata nilai masuk dalam kategori tinggi maka dapat disimpulkan kedisiplinan aparatur birokrasi sudah baik namun demikian tentunya masih harus lebih ditingkatkan lagi karena kedisiplinan sebagai aspek yang diperhatikan dalam menilai prilaku birokrasi.

Disiplin sangat penting dalam rangka usaha untuk menjamin terpeliharanya tata tertib, kelancaran pelaksanaan tugas serta berjalannya organisasi secara efektif. Oleh karena itu setiap organisasi perlu menanamkan masalah kedisiplinan karena berdampak pada efektivitas kerja organisasi.

Temuan ini memberi arti bahwa dalam upaya menampilkan kinerja yang baik untuk pemberian kualitas pelayanan kepada masyarakat, serta dalam rangka menjalankan tugas dan fungsinya aparatur (paramedis) yang bertugas di puskesmas telah memiliki perilaku yang baik. Perilaku yang dimaksudkan adalah sebagai bentuk aktualisasi sikap dalam melaksanakan tugas dan fungsinya sebagai paramedis (perawat dan bidan) dalam memberikan pelayanan kepada pasien belum optimal.

Baik buruknya perilaku biropkrasi ini, kemungkinan berkaitan dengan tradisi birokrasi di Indonesia yang sampai sekarang masih berakar kepada tradisi birokrasi pemerintah yang bersifat patrimonial yang berasal dari sistem kerajaan dimasa lampau. Mereka hanya membangun kepatuhan dan loyalitas terhadap kekuasaan, birokrasi yang seharusnya impersonal menjadi sangat personal.

Keberhasilan aparatur dalam memberikan kualitas pelayanan kesehatan ditentukan oleh perilaku aparatur ( paramedis ) dalam mengikuti peraturan, sistem dan standar pelayanan kepada masyarakat. 


\section{Pengaruh Motivasi dan Perilaku aparatur Terhadap Kualitas Pelayanan Kesehatan}

Permasalahan yang akan dijawab adalah seberapa besar pengaruh motivasi dan perilaku aparatur birokrasi terhadap kualitas pelayanan kesehatan di Puskesmas Kota Palu. Besarnya pengaruh motivasi dan perilaku aparatur birokrasi yang terdiri atas kepedulian, kedisiplinan, kepekaan dan tanggung jawab terhadap kualitas pelayanan kesehatan diperlihatkan dengan nilai koefisien determinasi $\mathrm{R}^{2}$ pada tabel 4.67. Diperoleh pengaruh motivasi dan perilaku aparatur birokrasi terhadap kualitas pelayanan kesehatan di puskesmas Kota Palu sebesar 0.80 sehingga dapat dikatakan bahwa besarnya pengaruh motivasi dan perilaku aparatur terhadap kualitas pelayanan kesehatan adalah $80 \%$, sedangkan besarnya faktor lain yang mempengaruhi adalah $100 \%-80 \%=20 \%$

Hasil penelitian ini mengindikasikan bahwa semakin tinggi motivasi dan perilaku yang dimiliki aparatur di puskesmas Kota Palu yang dicerminkan oleh dimensi eksistensi, hubungan, pengembangan, kepedulian, kedisiplinan, kepekaan, dan tanggung jawab. Hal ini akan diikuti oleh semakin tinggi kualitas pelayanan kesehatan yang dicerminkan oleh dimensi kemudahan, kecepatan, ketepatan, dan keadilan dilakukan oleh aparatur di puskesmas Kota Palu. Selanjutnya dapat dijelaskan pada persamaan jalur $\eta_{1}=0,55 \xi_{1}+0,49 \xi_{2}$. Dengan persamaan jalur tersebut dapat diinterpretasikan bahwa variabel motivasi berpengaruh paling besar dibandingkan variabel prilaku aparatur birokrasi terhadap kualitas pelayanan kesehatan. Berdasarkan hasil analisis data menggambarkan bahwa motivasi aparatur mempunyai hubungan dengan perilaku aparatur. Sebagaimana yang dikemukakan oleh Gibson dkk (1986:93) bahwa motivasi berhubungan dengan perilaku dan kinerja. Dengan demikian keberadaan motivasi dan perilaku bersinergi dalam pencapaian tujuan organisasi.

Berdasarkan temuan penelitian yang menunjukkan adanya pengaruh yang signifikan antara perilaku aparatur birokrasi dengan kualitas pelayanan kesehatan maka dapat dikatakan bahwa beberapa dimensi yaitu peduli, disiplin, peka, dan tanggung jawab variabel perilaku aparatur memberikan pengharuh yang penting terhadap kualitas pelayanan kesehatan di Puskesmas Kota Palu, dengan dimensi kemudahan, kecepatan, ketepatan dan keadilan.

Di dukung oleh pendapat Siagian (1994), Thoha (2002), Ndraha (2003) bahwa perilaku aparatur dipandang sebagai sikap, bentuk, tindakan dari ketentuan yang telah ditetapkan dalam melaksanakan tugas dan pekerjaannya sebagai abdi Negara, yang tercermin dalam peduli,disiplin, peka dan tanggung jawab dalam rangka memberikan pelayanan kepada masyarakat. Dengan demikian perilaku aparatur merupakan fakltor yang mempengaruhi kualitas pelayanan.

Sebagaimana diketahui hasil perhitungan $S E M$, menunjukkan pengaruh perilaku aparatur $\left(\xi_{2}\right)$ terhadap kualitas pelayanan $(\eta)$ sebesar 0.49 standar deviasi atau $24 \%$ keragaman dari kualitas pelayanan kesehatan dijelaskan oleh prilaku aparatur. Jika dibandingkan dengan persentase dari hasil perhitungan SEM variabel 
motivasi $(30.25 \%)$, perilaku aparatur birokras memberikan pengaurh yang lebih kecil terhadap kualitas pelayanan kesehatan. Walaupun kecil tetapi mempunyai makna yang signifikan terhadap kualitas pelayanan kesehatan.

Rendahnya pengaruh perilaku aparatur terhadap kualitas pelayanan kesehatan, disebabkan karena belum dilaksanakan secara optimal perilaku yang sesuai dengan peranannya sebagai abdi Negara dan abdi masyarakat. Keseluruhan perilaku para anggota birokrasi tercermin pada pelayanan kepada seluruh masyarakat, menurut Siagian (1994:91).

Pelayanan kepada masyarakat dapat dikatakan berkualitas apabila aparatur mampu menumbuhkan harapan yang di dambakan oleh pasien ketika mendapatkan pelayanan yang diberikan oleh aparatur puskesmas sebagai pemberi pelayanan. Apabla harapannya terlampaui, berarti jasa tersebut telah memberikan suatu kualitas yang luar biasa dan juga akan menimbulkan kepuasan yang sangat tinggi. Sebaliknya, apabila harapan itu tidak tercapai, maka diartikan kualitas jasa tersebut tidak memenuhi apa yang diinginkan atau penyedia jasa pelayanan tersebut gagal melayani pasien.

Untuk menciptakan kualitas pelayanan kesehatan yang berkualitas, maka dimensi kualitas pelayanan harus dijalankan dengan baik. Dimensi kemudahan memiliki skor rata-rata sebesar $71.9 \%$ termasuk kategori baik dengan koefisen jalur dari variabel kualitas pelayanan terhadap dimensi kemudahan sebesar 0.79 juga masuk dalam kategori tinggi dan merupakan dimensi yang paling dominan dalam mengukur variabel laten kualitas pelayanan kesehatan. Hal ini mendiskripsikan bahwa kemudahan merupakan aspek yang sangat diperhatikan dalam kaitannya dengan pelayanan kesehatan yang berkualitas. Kemudahan tersebut diantaranya meliputi kemudahan menghubungi petugas, puskesmas mudah dijangkau, kemudahan memperoleh informasi dengan menggunakan tenaga paramedis yang tidak begitu banyak jumlahnya merupakan indikator. Hal ini dapat dipengaruhi oleh mekanisme pelayanan yang memperhatikan efisiensi pelayanan.

\section{SIMPULAN}

Motivasi aparatur birokrasi berpengaruh terhadap kualitas pelayanan kesehatan di Puskesmas Kota Palu. Hal ini menunjukkan bahwa motivasi aparatur birokrasi memberikan sumbangan yang tinggi terhadap kualitas pelayanan kesehatan di puskesmas Kota Palu. Semakin tinggi motivasi aparatur birokrasi, maka semakin tinggi juga kualitas pelayanan kesehatan di puskesmas Kota Palu. Dimensi motivasi yang paling dominan dalam merefleksikan variabel motivasi adalah ekisistensi.

Perilaku aparatur birokrasi berpengaruh cukup terhadap kualitas pelayanan kesehatan pada Puskesmas Kota Palu. Hal ini mengandung arti bahwa perilaku aparatur birokrasi memberikan masukan yang cukup terhadap kualitas pelayanan kesehatan di puskesmas Kota Palu. Dimensi perilaku aparatur birokrasi yang paling dominan dalam merefleksikan variabel perilaku aparatur adalah tanggung jawab. 
Hasil penelitian ini menjelaskan bahwa motivasi aparatur berpengaruh lebih tinggi terhadap kualitas pelayanan kesehatan jika dibandingkan dengan perilaku aparatur terhadap kualitas pelayanan kesehatan. Sehingga dengan demikian disarankan untuk mengadakan penelitian kuantitatif lanjutan dengan maksud mengadakan pengujian teori yang lebih mendalam tentang hubungan motivasi terhadap kualitas pelayanan kesehatan.

Dalam rangka meningkatkan motivasi aparatur terhadap kualitas pelayanan kesehatan, maka aparatur (paramedis) menjalankan tugas dan fungsinya sebagai pemberi pelayanan kesehatan kepada masyarakat. Kepala dinas kesehatan sebagai pengambil kebijakan di Kota Palu memperhatikan masalah pengembangan aparaturnya di Puskesmas. Yang perlu diperhatikan antara lain pendidikan dan pelatihan aparatur dalam bentuk pelatihan APN (Asuhan Persalinan Normal).

\section{DAFTAR PUSTAKA}

Greene, Charles N., Everett E, Adam Jr. dan Ronald J, Ebert. 1985. Management for Effective Performance. Englewood Cliffs, Nj: Printice-Hall, Inc.

Jones, Gareth R., Jennifer M. George., dan Charles W.L., Hill. 2000. Contemporary Management. Borton: Mc Graw-Hill

Koehler, Michael and Hal G, Rainey. 2008 "Interdisciplinary Fundations of Public Service Motivation". In James L. Perry. Motivation in Public Management: The Call of Public Service. Page 33-35. New York: Oxford University Press.

Ndraha, Taliziduhu. 2003. Kibernology (IImu Pemerintahan Baru) I, Jakarta : Rineka Cipta.

Siagian, Sondang P. 1994. Patologi Birokrasi - Analisis, Identifikasi dan terapannya, Jakarta : Ghalia Indonesia.

Sunarto. 2008. Pengaruh Komunikasi dan Motivasi Kerja Aparatur Terhadap Kualitas Pelayanan Sertifikat Tanah di Kantor Pertanahan Kota Madya Jakarta Selatan. Disertasi, Bandung.Unpad

Toha, Miftah. 2002. Perpektif Perilaku Birokrasi. Dimensi-dimensi Prima IImu Administrasi Negara. Jakarta : PT Radja Grafindo Persada. 